\title{
Reconstrucción de cuero cabelludo con colgajo libre de omentum
}

\section{Reconstruction of the scalp with a free flap of omentum}

\author{
C. Navarro Cuellar1, F. Riba García' , B. Guerra Martínez², R. Pujol Romanya ${ }^{1}$, H. Herencia Nieto', \\ C. Navvarro Vila ${ }^{3}$
}

Resumen: Los defectos de cuero cabelludo pueden tener una etiología diversa. Resecciones oncológicas, lesiones postraumáticas e infecciosas pueden dar lugar a diferentes defectos en cuanto a tamaño y extensión. Para su reconstrucción disponemos de múltiples técnicas quirúrgicas como colgajos locales, regionales y expansores titulares. No obstante, para defectos extensos los colgajos libres son la única posibilidad reconstructiva. Presentamos el caso de un paciente con carcinomas epidermoides multicéntricos en cuero cabelludo tratado previamente con radioterapia en el que se realizó una resección amplia del cuero cabelludo y fue reconstruído con un colgajo libre de omentum.

Palabras clave: Cuero cabelludo; Colgajo libre de omentum.

\section{Introducción}

El cuero cabelludo es una zona ricamente vascularizada y constituída por múltiples capas descritas clásicamente con las siguientes siglas: SCALP(S, skin; $C$, subcutaneous tissue; $A$, aponeurosis o gálea; $L$, loose connective tissue; $P$, pericranium) ${ }^{1}$. Todas estas capas presentan una consistencia anatómica importante excepto a nivel de la región temporal donde encontramos la fascia temporoparietal que posteriormente se convierte en gálea en la línea temporal inferior y la fascia del músculo temporal con su músculo ubicados entre la gálea y el pericráneo.

\footnotetext{
1 Médico Residente

2 Médico Adjunto

3 Jefe de Servicio. Catedrático de Cirugía Maxilofacial

Servicio de Cirugía Maxilofacial

Hospital General Universitario Gregorio Marañón. Universidad Complutense, Madrid
}

Correspondencia:

Carlos Navarro Cuéllar

C/ María Molina $60,7^{\circ} \mathrm{A}$

28006 Madrid

E-mail: cnavarrocuellar@mixmail.com

\begin{abstract}
Scalp defects may have different etiologies. Oncologic resections, postraumatic lesions and infectious wounds may lead to a great variety of defects in size and extension. In order to accomplish the reconstruction we have different surgical techniques such as local and regional flaps and tissue expanders. Nevertheless, for more extensive defects free flaps are the only reconstructive possibility. We present the case of a patient with multicentric squamous cell carcinomas previously with radiotherapy. He underwent wide resection and was reconstructed with an omentum free flap.
\end{abstract}

Keywords: Scalp; Omentum free flap.

\section{Introduction}

The scalp is an area which is richly vascularized and which has classically been described with the following acronym: SCALP (S: skin; C subcutaneous tissue; A, aponeurosis or galea; $L$, loose connective tissue; $P$, pericranium) 1 . All these layers have an important anatomical consistency with the exception of the layer in the temporal region where we find the temporoparietal fascia, which then becomes galea by the inferior temporal line, and the fascia of the temporalis muscle with its muscle situated between the galea and the pericranium.

The scalp is relatively inelastic compared with the rest of the cervicofacial tissues. This is largely due to the fibrous union formed by the galea with the frontal muscle in front and the occipital muscle behind. ${ }^{1}$ Most scalp flaps as a consequence resist traction and transposition, and they often require more extensive designs for closing defects.

On the other hand, the scalp has the great advantage of its rich vascular supply. Irrigation to the scalp is done by five vascularized pedicles in each side, namely: the supratrochlear artery, the supraorbital artery, the superficial temporalis artery with its frontal and parietal branches, the pos- 
El scalp es relativamente poco elástico comparado con el resto de los tejidos cervicofaciales. Esto es debido, en gran parte, a la unión fibrosa que forma la gálea con el músculo frontal por delante y el músculo occipital por detrás. ${ }^{1}$ Como consecuencia, la mayoría de los colgajos de cuero cabelludo resisten la tracción y la transposición, y a menudo requieren diseños más extensos para el cierre de sus defectos.

Por otro lado, el cuero cabelludo tiene la gran ventaja de su rico aporte vascular. La irrigación del scalp se realiza a través de 5 pedículos vasculares en cada lado, a saber: arteria supratroclear, arteria supraorbitaria, arteria temporal superficial con sus ramas frontal y parietal, arteria auricular posterior y arteria occipital. Todos estos vasos presentan anastomosis entre sí y sobrepasan la línea media para conectarse con los vasos contralaterales. Toda esta rica red vascular confiere al scalp una gran resistencia a la necrosis de sus colgajos. ${ }^{2}$

Los defectos de cuero cabelludo pueden ser producidos por múltiples etiologías (resecciones oncológicas, defectos postraumáticos, infecciosos, etc.). La reconstrucción de los mismos se puede realizar de diferentes formas dependiendo, fundamentalmente, del tipo y extensión del defecto. Cierre primario, cicatrización por segunda intención, expansores titulares, injertos de piel y colgajos locales son las métodos clásicos para la reconstrucción de defectos de scalp no muy extensos. No obstante, defectos mayores no pueden ser reconstruídos mediante estas técnicas y precisan de colgajos microvascularizados para su reparación.

El colgajo libre de omentum fue utilizado por primera vez por Kiricuta ${ }^{3}$ en 1963 para la reconstrucción de mama en cirugía oncológica. Posteriormente Dupont y Menard ${ }^{4}$ emplean este colgajo para reconstruir defectos torácicos demostrando su capacidad para aportar volumen y su gran vascularización.

En 1972 McLean y Buncke ${ }^{5}$ utilizan por primera vez el omentum como colgajo libre para la reconstrucción de un defecto de cuero cabelludo cubriéndolo con un injerto dermoepidérmico. Brown ${ }^{6}$ describe la reparación de un defecto de tercio medio facial con un injerto de costilla y el colgajo de omentum para aportar

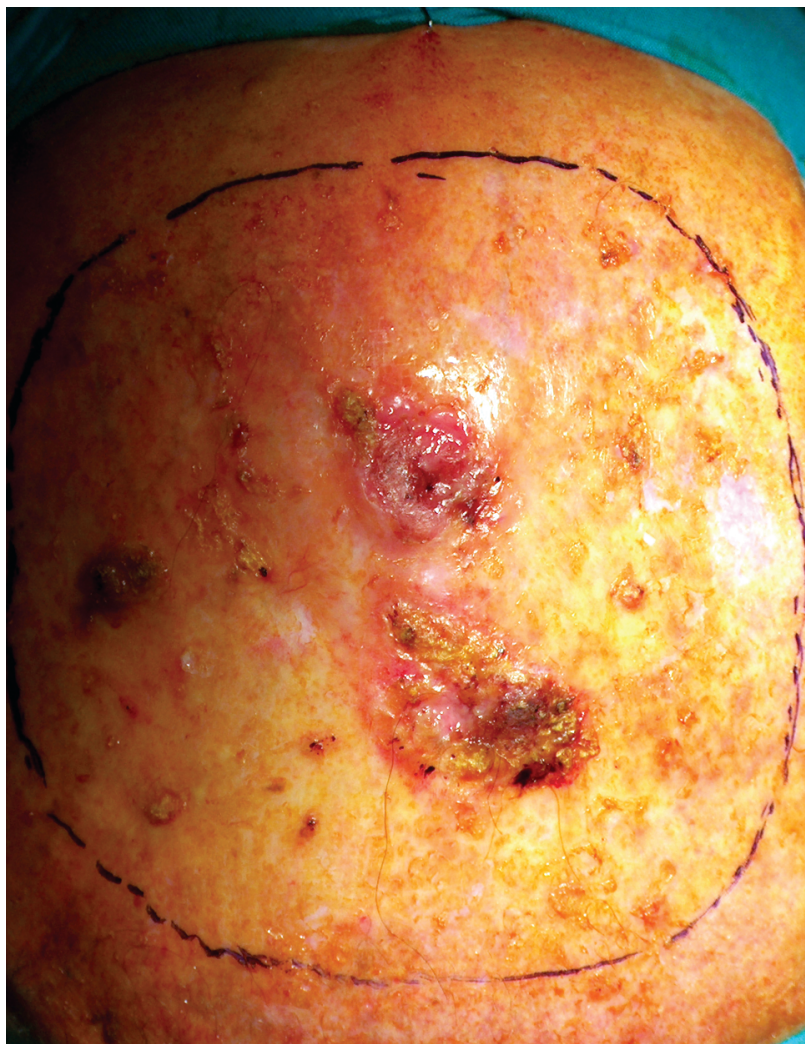

Figura 1. Carcinoma epidermoide multicéntrico. Diseño de la resección quirúrgica.

Figure 1. Multicentric squamous cell carcinoma. Design of surgical resection.

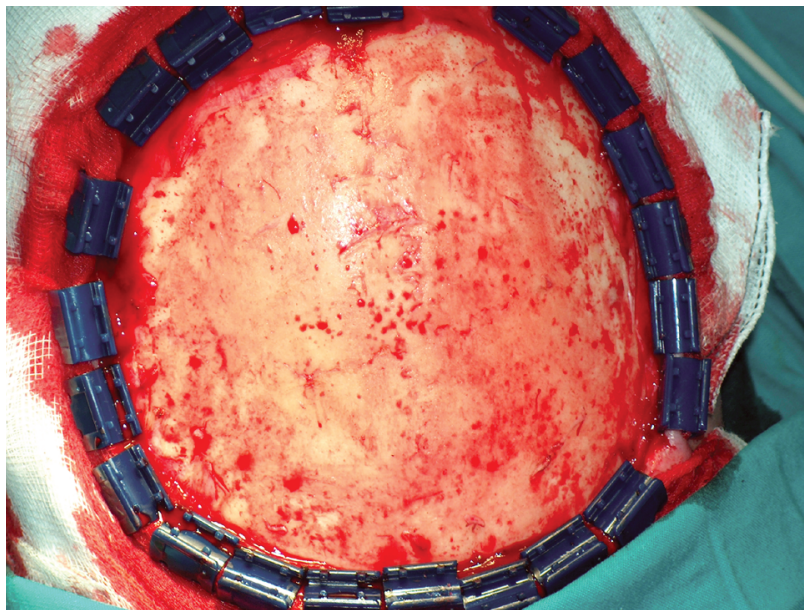

Figura 2. Defecto creado tras la resección de la lesión. Figure 2. Defect created following resection. terior auricular artery and occipital artery. All these vessels allow anastomosis and they cross the mid-line in order to connect with the contralateral vessels. All this rich vascular network gives the scalp great resistance to necrosis in its flaps. ${ }^{2}$

The defects of the scalp can be produced by multiple etiologies (oncologic resection, post-traumatic defects, infections, etc.). This reconstruction can be done in different ways depending, fundamentally, on the type and extension of the defect. Primary closure, second intention healing, tissue expanders, skin grafts, local flaps are the classic methods for the reconstruction of scalp defects that are not very extensive. Nevertheless, larger defects cannot be reconstructed by means of this technique and microvascular flaps are needed for their repair.

The omentum free flap was first used by Kiricuta ${ }^{3}$ in 1963 for breast reconstruction in oncologic surgery. Later Dupont and Menard 4 used this flap for reconstructing thoracic defects demonstrating its capacity for providing volume and its considerable vascularization.

In 1972 McLean and Bunckes used the omentum for the first time as a free flap for the reconstruction of a scalp defect, covering it with a dermoepidermic graft. Brown6 described the repair of a defect in the middle third of the face with a rib graft and an omentum flap for providing volume. Wallace ${ }^{7}$ and Upton $^{8}$ used this flap for the reconstruction of hemifacial atrophy, and Panje 9,10 for treating maxillary and mandibular osteoradionecrosis. From then on, the omentum free flap has been used extensively for the reconstruction of the head and neck. 
volumen. Wallace ${ }^{7}$ y Upton ${ }^{8}$ emplean este colgajo para reconstrucción de atrofia hemifacial y Panje 9,10 para tratar la osteorradionecrosis maxilar y mandibular. Desde entonces, el colgajo libre de omentum ha sido ampliamente utilizado en cirugía reconstructiva de cabeza y cuello.

\section{Caso clínico}

Presentamos el caso de un paciente de 68 años con ausencia de pelo en el cuero cabelludo, con antecedentes de hernia inguinal derecha no operada y con una queratosis actínica de años de evolución tratada inicialmente con retinoides y crioterapia. Dos años más tarde el paciente refiere aparición de varias lesiones costrosas en la región parieto-occipital. Se toman biopsias de las lesiones informando como Carcinoma epidermoide de moderado grado de diferenciación. Se realiza extirpación de las lesiones quedando uno de los márgenes de la resección afectado por el tumor. Al paciente se le administra radioterapia a dosis máximas en el cuero cabelludo. 6 meses después el paciente refiere aparición de varias lesiones similares a las previas en la misma zona. Se toman nuevas biopsias informando como Carcinoma epidermoide. El paciente, entonces, es remitido a nuestro Servicio para valorar las posibilidades terapéuticas. A su llegada el paciente presenta dos lesiones costrosas de aproximadamente 2 y $3 \mathrm{~cm}$. de diámetro respectivamente y otras lesiones de menor tamaño sospechosas de malig-

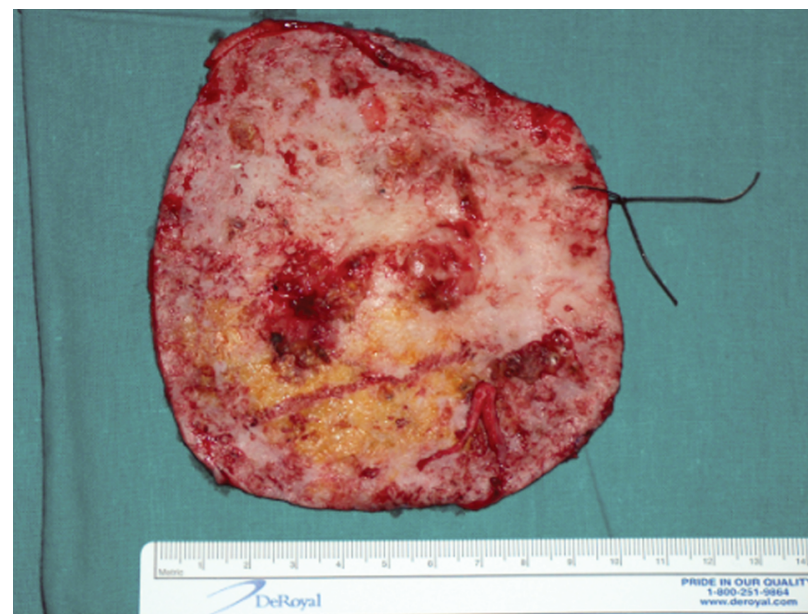

Figura 3. Pieza quirúrgica. Figure 3. Surgical specimen.

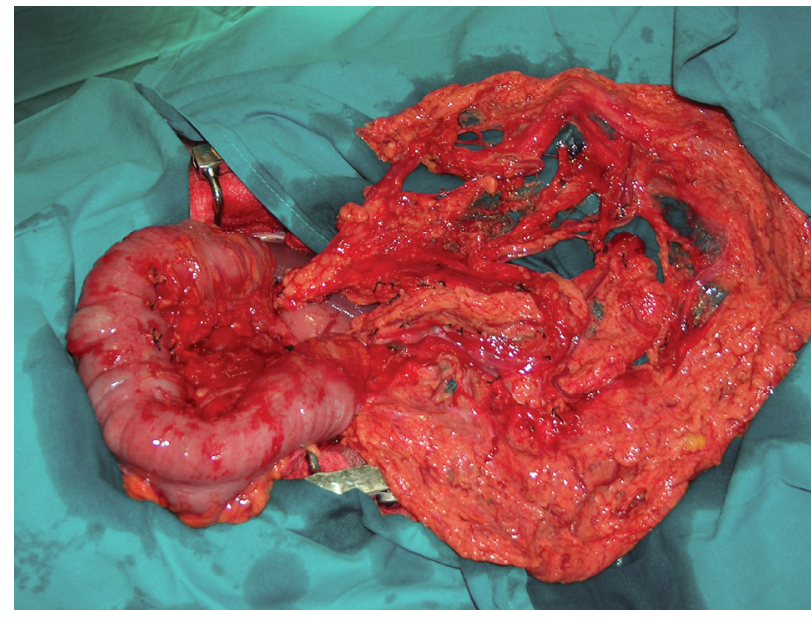

Figura 4. Colgajo de omentum antes de seccionar el pedículo gastroepiploico.

Figure 4. Omentum flap before sectioning the gastroepiploic pedicle.

\section{Clinical Report}

We present the case of a sixty-eight year old patient with no hair on his scalp, who had a history of inguinal hernia on the right side that had not been operated on, and with an actinic keratosis which had persisted for years which had initially been treated with retinoids and cryotherapy. Two years later the patient reported the appearance of various scabby lesions in the parieto-occipital region. Biopsies were performed on the lesions which were reported as squamous cell carcinoma with a moderate grade of differentiation. The lesions were removed and one of the margins was affected by the tumor. The patient's scalp underwent maximum dosage radiotherapy. Six months later, the patient reported the appearance of various lesions similar to the previous ones which were in the same area. nidad. De igual forma y, como consecuencia de la radioterapia, presenta una fibrosis y retracción completa del cuero cabelludo que impide cualquier tipo de reconstrucción mediante colgajos locales. Visto en sesión clínica se decide realizar una resección amplia del cuero cabelludo y reconstrucción inmediata del defecto con un colgajo libre de omentum a la vez que una herniorrafia para reducir la hernia inguinal que el paciente presenta.

El paciente es intervenido junto con el Servicio de Cirugía General y se realiza un abordaje con dos equipos de forma simultánea. Por un lado se realiza una extirpación amplia del cuero cabelludo junto con un abordaje preauricular bilateral para identificar y aislar los vasos temporales superficiales. Por otro, se realiza una laparotomía media. Una vez explorada la cavidad abdominal, se tracciona del omentum y se diseca desde el mesocolon transverso hacia arriba. A continuación identificamos el pedículo vascular correspondiente a los vasos gastroepiploicos derechos y se van exponiendo y ligando las pequeñas ramas vasculares que van a la zona posterior y anterior de la curvatura mayor del estómago. Una vez
New biopsies were performed and squamous cell carcinoma was reported. The patient was then sent to our Service so that the therapeutic possibilities could be evaluated. On arrival the patient presented two scabby lesions with a diameter of approximately 2 and $3 \mathrm{~cm}$ respectively, together with other smaller lesions that were suspicious for malignancy. Similarly, and as a consequence of the radiotherapy, the patient presented fibrosis and complete retraction of the scalp that impeded any type of reconstruction with local flaps. Studied during a clinical session, ample resection of the scalp was decided upon, together with immediate reconstruction of the defect using an omentum free flap and a herniorraphy to reduce the inguinal hernia the patient presented.

The patient was operated on in conjunction with the Service of General Surgery and a simultaneous two-team approach was used. On the one hand extensive extirpation was carried out of the scalp together with a bilateral preauricular approach in order to identify and isolate 
liberado el pedículo vascular de la curvatura mayor del estómago se liga el pedículo de la arteria gastroepiploica izquierda quedando el omentum pediculado a la arteria gastroepiploica derecha y preparado para ser transferido a la zona del defecto. A continuación se sutura el omentum al cuero cabelludo remanente y se realizan las anastomosis. Algunos autores utilizan ambos pedículos vasculares con doble anastomosis a los vasos faciales y a los temporales superficiales. ${ }^{8}$ En nuestro caso hicimos las anastomosis utilizando solamente el pedículo gastroepiploico derecho y como vasos receptores la arteria y vena temporal superficial. Finalmente, todo el colgajo de omentum es recubierto con un injerto dermoepidérmico mallado y se coloca un vendaje compresivo durante 1 semana. La pieza quirúrgica informó como Carcinomas epidermoides de moderado grado de diferenciación y dos Carcinomas in situ, todo con márgenes de resección libres de enfermedad. El postoperatorio transcurrió sin incidencias ni complicaciones y el paciente fue dado de alta a los 12 días de la cirugía. El paciente es seguido en revisiones múltiples y, 2 años después de la cirugía, no presenta signos de recidiva local. Desde el punto de vista estético el paciente se muestra muy satisfecho del resultado ya que las marcas del mallado de la piel han desaparecido con el tiempo y constituye un tejido uniforme a lo largo de todo el cuero cabelludo.

\section{Discusión}

La reconstrucción del cuero cabelludo depende, básicamente, del tipo, localización y extensión del defecto a reconstruir disponiendo de múltiples técnicas a tal efecto. Defectos pequeños de varios centímetros pueden ser reconstruídos de forma primaria. Los incovenientes de esta técnica son la alopecia residual y la escasa elasticidad del scalp que sólo permite el cierre de defectos limitados. Para disminuir la tensión en el cierre se deben realizar incisiones en la gálea paralelas a los bordes de la herida.

La cicatrización por segunda intención, a pesar de no ser utilizada de forma habitual, puede ser una forma efectiva de tratar el scalp. No obstante, presenta numerosos incovenientes tales como ausencia de pelo en la zona, fibrosis, retracción y desarrollo de cicatrices atróficas, telangiectasias y precisan de curas múltiples para evitar su sobreinfección.

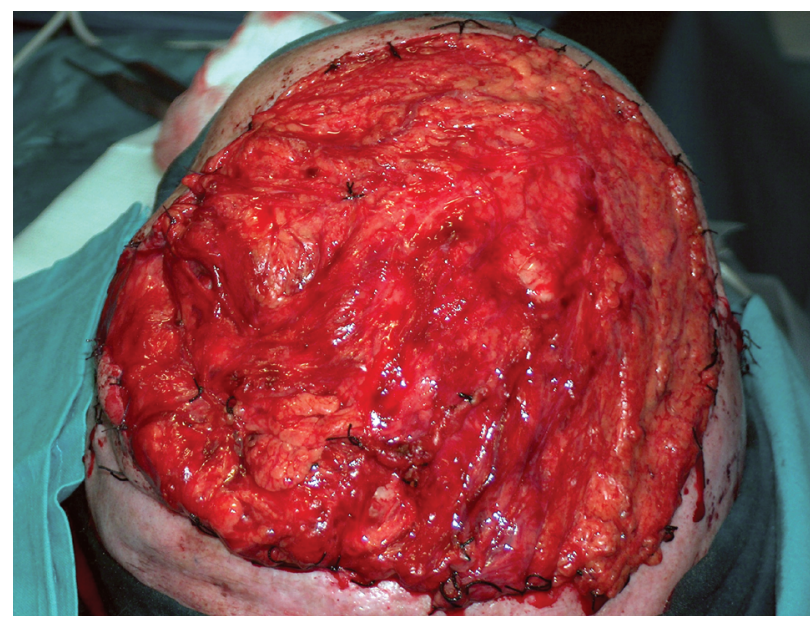

the superficial temporal vessels. On the other hand, a medial laparotomy was performed. Once the abdominal cavity had been explored, the omentum was tractioned and dissected from the transverse mesocolon upwards. Next the vascular pedicle corresponding to the right gastroepiploic vessels was identified and exposed, and the small vascular branches that run to the anterior and posterior greater curvature of the stomach were exposed and ligated. Once the vascular pedicle of the greater curvature of the stomach had been freed, the pedicle of the left gastroepiploic artery was ligated leaving the omentum pedicled to the right gastroepiploic artery and ready to be transferred to the area of the defect. The omentum was then sutured to the remaining scalp and the anastomoses carried out. Some authors use both vascular pedicles with double anastomosis to the facial vessels and to the superficial temporal [vessels]. ${ }^{8}$ In this case of ours, anastomosis was carried out using only the right gastroepiploic [artery], and the superficial temporal artery and vein were used as receptor vessels. Finally all the omentum flap was covered with a dermoepidermic mesh graft and a compression bandage was applied for one week. The surgical specimen was reported as squamous cell carcinoma with a moderate grade of differentiation and there were two carcinomas in situ, all with disease free margins. There were neither incidences nor complications during the postoperative period, and the patient was sent home 12 days after surgery. The patient attended numerous check ups and 2 years after the surgery there are no signs of local recurrence. From the aesthetic point of view the patient is very satisfied with the result, as the marks from the mesh have over time disappeared from his skin, and the tissue is uniform over his entire scalp. 
Los injertos de piel son otra opción utilizada clásicamente para reconstruir este tipo de defectos. Para que estos injertos prendan de forma adecuada en el lecho receptor precisan de tejido ricamente vascularizado por debajo como puede ser el pericráneo o la fascia. Al igual que la cicatrización por segunda intención, esta técnica debe ser limitada ya que confieren un pobre resultado estético y presentan tendencia al sangrado, dolor y ulceración.

Los expansores titulares han sido muy utilizados para reconstruir defectos de cuero cabelludo. Consiste en la colocación de un balón de Silastic por debajo de la gálea que se va inflando con suero salino de forma progresiva durante 6-8 semanas dependiendo del tamaño del defecto a reconstruir. Por lo general se debe expandir aproximadamente 2-2,5 veces el tamaño del defecto. ${ }^{11}$ El cuero cabelludo es una zona ideal para la colocación de expansores titulares gracias al grosor del tejido y a su gran vascularización. Otra de sus principales ventajas es la aportación de tejido con un color y una textura similar a la de la zona a reconstruir. De igual forma presentan problemas e incovenientes como exposición e infección del expansor y la necesidad de una segunda cirugía para la reconstrucción. Por lo general no suelen producir alopecia pero pueden dejar una sequedad o hiperpigmentación residual en la piel.

Los colgajos locales de avance y rotación constituyen el principal método reconstructivo para pequeños defectos y defectos de tamaño medio. Estos colgajos se tallan siguiendo los mismos principios básicos que los colgajos faciales salvo con la diferencia de que estos colgajos necesitan ser proporcionalmente más largos y anchos debido a la escasa elasticidad del cuero cabelludo. ${ }^{12}$ Es importante hacer varias consideraciones a este nivel. En primer lugar, el diseño del colgajo se debe realizar de forma que uno de los principales pedículos vasculares entre por la base del colgajo. En segundo lugar, se debe considerar la línea del pelo e intentar diseñar el colgajo de manera que las incisiones se sitúen por detrás de la misma para conseguir un mejor resultado estético. En tercer lugar, los colgajos se deben tallar en un plano subgaleal realizando incisiones en la gálea para disminuir la tensión del cierre. Finalmente, pueden ser necesarios varios colgajos para conseguir una reconstrucción completa del defecto.

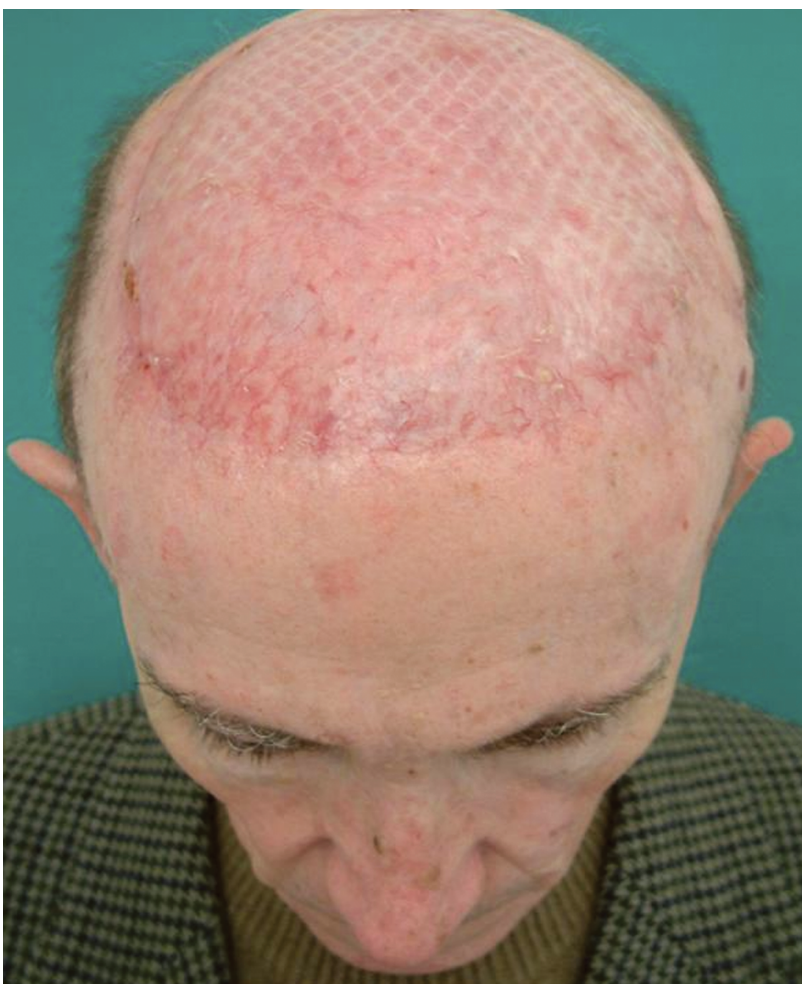

Figura 8. Aspecto a las 6 semanas. Figure 8. Appearance after 6 weeks.

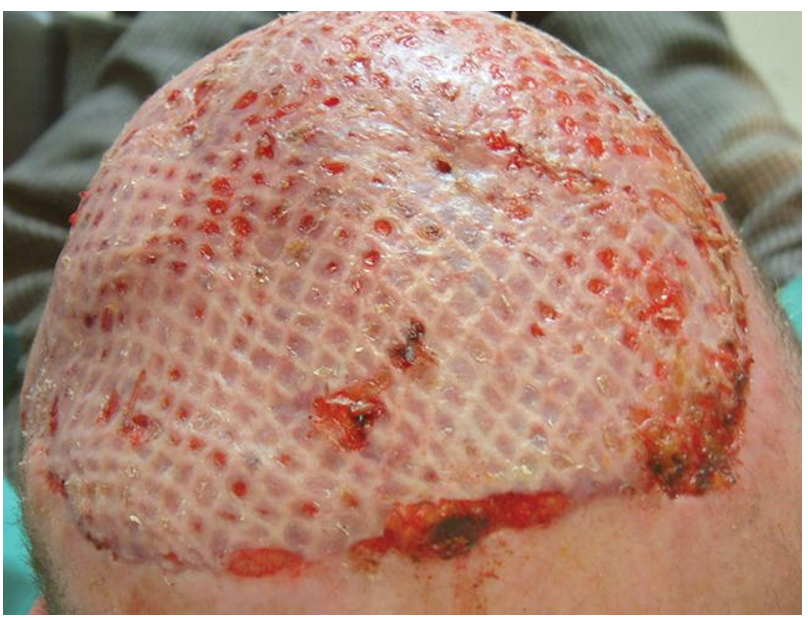

Figura 7. Aspecto del colgajo a los 7 días de la cirugía. Figure 7. Appearance of the flap 7 days after surgery.

\section{Discussion}

Reconstruction of the scalp depends basically on the type, location and extension of the defect that has to be reconstructed, and there are multiple techniques for doing this. Primary reconstruction can be used for small defects of various centimeters. The inconveniences of this technique are residual alopecia and the limited elasticity of the scalp which only permits the closure of limited defects. In order to reduce the tension of the closure, incisions should be made in the galea parallel to the borders of the wound.

Second intention healing, despite not being commonly used, can be an elective form of treating the scalp. Nevertheless, it has numerous inconveniences such as the absence of hair in the area, fibrosis, retraction and the development of atrophic scars, telangiectasias needing multiple treatments to avoid overinfection.

Skin grafts are another classical option used for reconstructing this type of defect. For these grafts to take adequately in the recipient bed, richly vascularized tissue is needed underneath such as pericranium or fascia. As in the case of second intention healing, this technique should be limited as the aesthetic result is poor and there is a tendency for bleeding,

pain and ulceration.

Tissue expanders have been widely used for reconstructing scalp defects. A Silastic ball is placed under the galea which is then filled progressively with saline serum for 6-8 weeks depending on the size of the defect to be reconstructed. Generally it should be expanded 2-2,5 times the size of the defect. ${ }^{11}$ The scalp is an ideal area for placing tissue expanders due to the thickness of the tissue and it being richly vascularized. Another of the principal advantages is the supply of 
Defectos amplios y extensos del cuero cabelludo precisan el uso de técnicas más sofisticadas para su reconstrucción como son las técnicas microquirúrgicas. ${ }^{13}$ Los colgajos microquirúrgicos aportan gran cantidad de tejido vascularizado para reconstruir grandes defectos de scalp. A pesar de que estos colgajos son seguros y predecibles, proporcionan un resultado estético pobre ya que presentan diferente textura y color de piel y ausencia de pelo. ${ }^{14} \mathrm{No}$ obstante, pueden representar la única opción reconstructiva en aquellos casos con una exposición craneal extensa en la que otros colgajos locales y regionales no pueden ser utilizados.

El omentum mayor es una doble capa de peritoneo que se extiende desde la curvatura mayor del estómago hasta su inserción en el colon transverso. La irrigación principal del omentum proviene de las arterias gastroepiploicas izquierda y derecha situadas por debajo de la curvatura mayor del estómago y dependientes ambas del tronco celíaco. La arteria gastroepiploica derecha es rama de la arteria gastroduodenal que, a su vez, sale de la arteria hepática y la arteria gastroepiploica izquierda es rama de la arteria esplénica. Ambas arterias gastroepiploicas forman una rica red vascular con anastomosis múltiples ${ }^{15}$ entre sí gracias a las 4 ramas principales de este plexo vascular: arteria omental accesoria, arteria omental derecha, arteria omental media y arteria omental izquierda. La arteria omental media acaba bifurcándose y dando ramas que se anastomosan con las arterias omentales izquierda y derecha.

Alday y Goldsmith ${ }^{16}$ describen 5 variantes anatómicas en una serie de 246 disecciones en cadáveres. Refieren 5 tipos diferentes de distribución y anastomosis del plexo vascular:

a. Tipo 1. La arteria omental media se divide en el tercio inferior del omentum anastomosándose a las arterias omental izquierda y derecha $(81,7 \%)$.

b. Tipo 2. La arteria omental media se divide en el tercio medio del omentum con anastomosis a las ramas terminales de las arterias omental izquierda y derecha (11\%).

c. Tipo 3. La arteria omental media se divide en el tercio medio del omentum en dos o tres ramas (4,5\%).

d. Tipo 4. Ausencia de arteria omental media que es sustituída por varias ramas omentales de pequeño tamaño $(1,2 \%)$.

e. Tipo 5. La arteria omental izquierda no se une a la arteria gastroepiploica izquierda a pesar de que las arterias omental media y derecha si salen de tronco de la arteria gastroepiploica derecha $(1,6 \%)$.

Estas variantes anatómicas son importantes a la hora de tallar el colgajo dependiendo de si queremos dividir o alargar el omentum para adaptarlo al defecto a reconstruir.

Por otro lado, existen considerables variaciones en cuanto a la longitud y diámetro del omentum. Das ${ }^{17}$ en una serie de 200 cadáveres correlaciona el tamaño del omentum con el peso y la talla del tissue with a similar color and texture to that of the area to be reconstructed. Similarly, problems and inconveniences arise such as exposure and infection of the expander and the need for secondary reconstruction surgery. Generally alopecia is not produced but dryness or residual hyperpigmentation is left in the skin.

Local advancement and rotation flaps constitute the principal reconstruction method for small and medium sized defects. These flaps are harvested following the same basic principles of facial flaps except with the difference that these flaps need to be proportionally longer and wider due to the lack of elasticity of the scalp..$^{12}$ It is important to bear in mind several considerations at this level. Firstly, the design of the flap has to be done in such way that one of the principal vascular pedicles enters through the base of the flap. Secondly, the hairline should be taken into account and an attempt should be made to design the flap in such a way that the incisions are situated behind it so that better aesthetic results are achieved. Thirdly, the flaps should be harvested in a subgaleal plane with incisions into the galea in order to reduce the tension of the closure. Finally, various flaps may be needed in order to achieve complete reconstruction of the defect.

Ample and extensive defects of the scalp require the use of more sophisticated techniques for reconstruction such as microsurgical techniques. ${ }^{13}$ Microsurgical flaps supply a large amount of vascularized tissue for reconstructing large scalp defects. In spite of these flaps being reliable and predictable, poor aesthetic results are achieved as they have different texture, skin color and no hair. ${ }^{14}$ Nevertheless, they may be the only reconstructive option in cases in which there is extensive exposure of the cranium and in which other local and regional flaps cannot be used.

The greater omentum is a double layer of peritoneum that extends from the greater curvature of the stomach to its insertion into the transverse colon. The principal source of irrigation of the omentum is from the left and right gastroepiploic arteries, situated under the greater curvature of the stomach, which both depend of the celiac trunk. The right gastroepiploic artery is a branch of the gastroduodenal artery which, in turn, arises from the hepatic artery and the left gastroepiploic artery is a branch of the splenic artery. Both gastroepiploic arteries form a rich vascular network with multiple anastosmosis ${ }^{15}$ due to the four principal branches of this vascular plexus: accessory omental artery, right omental artery, middle omental artery and left omental artery. 
paciente. No obstante, refiere que estos parámetros son muy limitados para predecir su tamaño ya que situaciones como la peritonitis o la cirugía abdominal previa producen retracción importante del omentum.

El pedículo vascular del colgajo libre de omentum está constituído por la arteria gastroepiploica derecha y sus dos venas comitantes, ya que presenta un mayor tamaño que la arteria gastroepiploica izquierda y recorre un mayor trayecto a lo largo de la curvatura mayor que esta última. ${ }^{18} \mathrm{La}$ arteria gastroepiploica derecha presenta un diámetro de 1,5-3 mm. mientras que en la arteria gastroepiploica izquierda el diámetro es de 1,2-2,9 mm.8,18

El colgajo libre de omentum ha sido ampliamente utilizado en cirugía reconstructiva de cabeza y cuello presentando múltiples ventajas. Por un lado tiene un pedículo vascular consistente en cuanto a tamaño y localización. Presenta un pedículo largo con capacidad para realizar las anastomosis a los vasos gastroepiploicos izquierdos o derechos en función también del tamaño de los vasos receptores. ${ }^{8}$ Por otro, la zona donante está alejada lo suficiente de la región cervicofacial como para poder trabajar en 2 equipos de forma simultánea y disminuir así el tiempo quirúrgico. ${ }^{5,7}$ Finalmente el colgajo de omentum es un colgajo muy manejable que permite moldearlo y doblarlo para conseguir un volumen adecuado y adaptarlo perfectamente al defecto a reconstruir. $5,6,8$

El principal incoveniente de este colgajo es la necesidad de realizar una laparotomía media para la obtención del mismo ya que pueden aparecer complicaciones como bridas y obstrucciones intestinales secundarias a la formación de vólvulos. ${ }^{19}$ Como alternativa a este colgajo y, para evitar complicaciones en la zona donante, el colgajo libre de músculo Latissimus Dorsi cubierto con injerto de piel ha sido muy utilizado en la reconstrucción de este tipo de defectos con un buen resultado estético y mínima morbilidad en la zona donante. ${ }^{20}$

Finalmente es importante reseñar el grado de atrofia que este colgajo puede experimentar en los primeros meses tras la cirugía. Algunos autores como Panje y Moran ${ }^{21}$ refieren una atrofia de aproximadamente un $20-50 \%$ en los 3 meses siguientes a la cirugía. No obstante, Upton 8 presenta una pequeña serie de 3 casos con un seguimiento de 2 años sin apenas variación en el volumen del colgajo. En nuestro caso el paciente sí ha experimentado una leve atrofia del colgajo si bien no llega a los porcentajes antes indicados.

Como conclusión de este trabajo queremos reseñar la capacidad del omentum mayor para reconstruir defectos extensos en longitud y volumen del cuero cabelludo. Constituye un colgajo seguro, predecible y su manejabilidad permite adaptarlo perfectamente al defecto. No obstante, el riesgo de una laparotomía media debe ser tenido muy en cuenta previamente ya que colgajos alternativos pueden reconstruir el mismo defecto con idénticos resultados estéticos y funcionales.

\section{Bibliografía}

1. Hoffmann JF. Management of scalp defects. Otolaryngol Clin North Am 2001;34(3):571-582.

2. Juri J, Juri C. Aesthetic aspects of reconstructive scalp surgery. Clin Plast Surg 1981;8:243.
The middle omental artery eventually divides providing branches that form anastomosis with the left and right omental arteries.

Alday and Goldsmith ${ }^{16}$ describe 5 anatomical variants in a series of 246 dissections of corpses. They reported five different types of distribution and anastomosis of the vascular plexus:

a. Type 1. The middle omental artery divides at the bottom third of the omentum forming anastomosis with the left and right omental arteries (81.7\%).

b. Type 2. The middle omental artery divides in the middle third of the omentum forming anastomosis with the terminal branches of the left and right omental arteries (11\%).

c. Type 3. The middle omental artery divides in the middle third of the omentum into two or three branches (4.5\%)

d. Type 4. Absence of middle omental artery which is substituted by various small omental branches (1.2\%).

e. Type 5. The left omental artery does not join the left gastroepiploic artery in spite of the middle and right omental artery arising from the right gastroepiploic artery (1.6\%).

These anatomical variants are important when harvesting the flap, depending on if we want to divide or elongate the omentum in order to adapt it to the defect that is to be reconstructed.

On the other hand there are considerable variations with regard to the length and diameter of the omentum. Das ${ }^{17}$ in a series of 200 corpses correlates the size of the omentum with the weight and size of the patient. Nevertheless, he reports that these parameters are very limited for predicting size, as situations such as peritonitis or previous abdominal surgery produce an important retraction of the omentum.

The vascular pedicle of the omentum free flap is made up of the right gastroepiploic artery and its two comitant veins, as it is larger in size than the left gastroepiploic artery and it covers a longer section along the greater curvature than the latter. 18 The right gastroepiploic artery has a diameter of 1.5-3 mm while the left gastroepiploic artery has a diameter of 1.2-2.9 mm.8,18

The omentum free flap has been widely used in reconstructive surgery of the head and neck as it has numerous advantages. It has on the one hand a vascular pedicle which is consistent in terms of size and location. It has a large pedicle that has the capacity for forming anastomosis with the left or right gastroepiploic vessels according to the size of the receptor vessels. ${ }^{8}$ On the other hand, the donor site is sufficiently away from the cervicofacial region so as to allow two teams to work simultaneously and thus reduce surgery time. ${ }^{5,7}$ Finally the omentum flap is a very manageable flap which can be molded and folded in order to achieve adequate volume, and it can be adapted perfectly to the defect that has to be reconstructed. $5,6,8$

The principal inconvenience is that in order to obtain this flap a medial laparotomy has to be performed and com- 
3. Kiricuta I. L`emploi du grand épiploon dans la chirurgie du sein cancereux. Presse Medicale 1963;71:15.

4. Dupont C, Menard Y. Transposition of the greater omentum for reconstruction of the chest wall. Plast Reconstr Surg 1972;49:263.

5. McLean D, Buncke HJ. Autotransplant of omentum to a large scalp defect with microsurgical revascularization. Plast Reconstr Surg 1972;49:268.

6. Brown R, Nahai F, Silverton J. The omentum in facial reconstruction. Br J Plastic Surg 1978;31:58-62.

7. Wallace JG, Schneider W], Brown R, Nahai F. Reconstruction of hemifacial atrophy with a free flap of omentum. Br J Plastic Surg 1979;32:15-18.

8. Upton J, Mulliken JB, Hicks PD, Murray JE. Restoration of facial contour using free vascularized omental transfer. Plast Reconstr Surg 1980;66:560.

9. Panje W, Pitcock J, Vargish T. Free omental flap reconstruction of complicated head and neck wounds. Otolaryngol Head Neck Surg 1989;100:588-593.

10. Moran W, Panje W. The free greater omental flap for treatment of mandibular osteoradionecrosis. Arch Otolaryngol Head Neck Surg 1987;13:425-427.

11. Sasaki GH. Tissue expanders and general guidelines for tissue expansion technique. In Tissue expansion in reconstructive and aesthetic surgery. St Louis, Mosby, 1998;11-14.

12. Ahuja RB. Geometric consideration in the design of rotational flaps in the scalp and forehead region. Plast Reconstr Surg 1988;81:900.

13. Furnas H, Lineaweaver WC, Alperts BS, Buncke HJ. Scalp reconstruction by microvascular free tissue transfer. Ann Plast Surg 1990;24:431.

14. Lutz BS, Wei FC, Chen HC et al. Reconstruction of scalp defects with free flaps in 30 cases. Br J Plastic Surg 1998;51:186.

15. El -Eishi H, Ayoub S, Abd-el-khalek M. The arterial supply of the human stomach. Acta Anat 1973;86:565-580.

16. Alday ES, Goldsmith HS. Surgical technique for omental lengthening based on arterial anatomy. Surg Gynecol Obstet 1972;135:103.

17. Das $S$. The size of the human omentum and methods of lengthening it for transplantation. Br J Plastic Surg 1976;29:170-174.

18. Urken ML, Cheney ML, Sullivan MJ, Biller HF. Atlas of regional and free flaps for head and neck reconstruction. Raven Press 1995;328:7-10.

19. Hakelius L. Fatal complication after the use of greater omentum for reconstruction of the chest wall: case report. Plast Reconstr Surg 1978;62:796.

20. Gordon L, Buncke HJ, Alpert B. Free latissimus dorsi muscle flap with split-thickness skin graft cover: report of 16 cases. Plast Reconstr Surg 1982;70:173. plications can appear such as bridles and secondary intestinal obstruction caused by the formation of volvulus. ${ }^{19}$ As an alternative to this flap, and to avoid complications in the donor site, the free latissimus dorsi muscle flap with a skin graft cover has been used frequently in the reconstruction of this type of defect with good aesthetic results and minimum donor site morbidity. ${ }^{20}$

Finally, it is important to report the degree of atrophy that can be experienced with this flap during the first months following surgery. Some authors such as Panje and Moran ${ }^{21}$ reported atrophy of approximately 20-50\% in the three months following surgery. Nevertheless, Upton ${ }^{8}$ presented a small series of three cases with a 2 year following in which there was hardly any variation in the volume of the flap. In our case the patient did experience a small amount of atrophy in the flap although not to the extent of the percentages previously indicated.

To conclude we would like to stress the capacity of the greater omentum in the reconstruction of scalp defects that are extensive in length and in volume. It constitutes a reliable and predictable flap and, being easy to handle, it can be adapted perfectly to the defect. Nevertheless, the risk of a medial laparotomy has to be previously and seriously taken into account, as alternative flaps for reconstructing the same defect can be used with identical aesthetic and functional results. 